\title{
Forum Non Conveniens and American Plaintiffs in the Federal Courts
}

In Gulf Oil Corp. v. Gilbert, ${ }^{1}$ the Supreme Court held that federal courts have discretion to dismiss suits properly within their jurisdiction under the doctrine of forum non conveniens. ${ }^{2}$ The doctrine makes dismissal appropriate whenever another forum exists where the suit may be brought, ${ }^{3}$ and either the plaintiff's choice of forum is so vexatious or oppressive to the defendant "as to be out of all proportion to plaintiff"s convenience," or "trial in the chosen forum [is] inappropriate because of considerations affecting the court's own administrative and legal problems."

Although the number of cases to which the doctrine is applicable has been significantly reduced since the Gulf Oil decision by judicial $^{b}$ and legislative ${ }^{7}$ developments, it has still been invoked to deprive plaintiffs of an American forum. ${ }^{8}$ The courts remain di-

1330 U.S. 501 (1947).

2 Forum non conveniens does not apply unless jurisdiction and venue are proper in the court in which the action is originally brought. Id. at 504.

3 See generally P. Bator, P. Mishkin, D. Shapiro, \& H. Wechsler, Hart \& Wechsler's The Federal Courts and the Federal System 1133-41 (2d ed. 1973) [hereinafter cited as Hart \& Wechsler]; A. Ehrenzweig, A Treatise on the Conflict of Laws $\$$ 30-37 (1962); F. James \& G. Hazard, Civil Procedure $§ 12.29$ (2d ed. 1977); 1A J. Moore, Federal Practice II 0.204 (2d ed. 1979); Restatement (Second) of Conflict of Laws \$ 84 (1971); 15 C. Wright, A. Miller \& E. Cooper, Federal Practice and Procedure § 3828 (1976); Barrett, The Doctrine of Forum Non Conveniens, 35 CaLIf. L. REv. 380 (1947); Bickel, The Doctrine of Forum Non Conveniens as Applied in the Federal Courts in Matters of Admiralty, 35 Connell L.Q. 12 (1949); Blair, The Doctrine of Forum Non Conveniens in Anglo-American Law, 29 CoLum. L. REv. 1 (1929); Braucher, The Inconvenient Federal Forum, 60 HaRv. L. Rev. 908 (1947); Dainow, The Inappropriate Forum, 29 ILL. L. Rev. 867 (1935); Morley, Forum Non Conveniens: Restraining Long-Arm Jurisdiction, 68 Nw. U.L. Rev. 24 (1973); Note, The Proper Role of the Residence Factor in Forum Non Conveniens Motions, 45 S. CAL. L. REv. 249 (1972); Note, The Convenient Forum Abroad Revisited: A Decade of Development of the Doctrine of Forum Non Conveniens in International Litigation in the Federal Courts, 17 VA. J. INT'L L. 755 (1977); Annot., 10 A.L.R. Fed. 352 (1972).

+ Gulf Oil Corp. v. Gilbert, 330 U.S. at 506-07.

- Koster v. Lumbermens Mut. Cas. Co., 330 U.S. 518, 524 (1947).

- See text and notes at notes 31-44 infra.

Tee text and notes at notes 28-30 infra.

${ }^{8}$ E.g., Alcoa S.S. Co. v. M/V Nordic Regent, No. 78-7054 (2d Cir. Feb. 25, 1980) (en banc); Mizokami Bros., Inc. v. Baychem Corp., 556 F.2d 975 (9th Cir. 1977) (per curiam), cert. denied, 434 U.S. 1035 (1978); Vanity Fair Mills, Inc. v. T. Eaton Co., 234 F.2d 633 (2d 
vided, however, over whether a greater showing of "inconvenience" should be required to deprive an American plaintiff, in contrast with a foreign plaintiff, of an American forum. ${ }^{\circ}$

This comment examines the propriety of allowing a plaintiff's American citizenship to weigh against dismissal in favor of a more convenient foreign forum. It argues that the status of citizenship, by itself, does not warrant the imposition of a higher burden of inconvenience on defendants who seek dismissal on grounds of forum non conveniens. While American citizens as a class often possess characteristics that make dismissal inappropriate, citizenship is a bad proxy for these characteristics. Such characteristics can be more appropriately dealt with on a case-by-case basis.

\section{The Doctrine of Forum Non Conveniens}

In Cohens $v$. Virginia, ${ }^{10}$ Chief Justice Marshall remarked in dictum that a federal court may not dismiss a case properly within its jurisdiction. ${ }^{11}$ Although that early view was echoed occasionally by the courts, ${ }^{12}$ it has plainly lost its force today. The Supreme

Cir.) (alternative holding), cert. denied, 352 U.S. 871 (1956); Texaco Trinidad, Inc. v. Astro Exito Navegacion S.A., Panama, 437 F. Supp. 331 (S.D.N.Y. 1977); Bernuth Lembcke Co. v. Siemens Aktiengesellschaft, 1976 Am. Mar. Cas. 2175 (S.D.N.Y. 1976); Mohr v. Allen, 407 F. Supp. 483 (S.D.N.Y. 1974).

- Compare Alcoa S.S. Co. v. M/V Nordic Regent, No. 78-7054, slip op. at 5960-69, 5973 (2d Cir. Feb. 25, 1980) (en banc) (no greater showing of inconvenience required) with Founding Church of Scientology v. Heinrich Bauer Verlag, 536 F.2d 429, 435 (D.C. Cir. 1976) (greater showing of inconvenience required); Olympic Corp. v. Societe Generale, 462 F.2d 376, 378 (2d Cir. 1972) (same); Hoffman v. Goberman, 420 F.2d 423, 426-27 (3d Cir. 1970) (same); Burt v. Isthmus Dev. Co., 218 F.2d 353, 357 (5th Cir. 1955) ("courts should require positive evidence of unusually extreme circumstances, and should be thoroughly convinced that material injustice is manifest before exercising any such discretion to deny a citizen access to the courts of his country"); United States Merchants' \& Shippers' Ins. Co. v. A/S Den Norske Afrika Og Australie Line, 65 F.2d 392, 393 (2d Cir. 1933) (Hand, J.) (dictum) (American citizenship should be conclusive against dismissal); and Top Form Mills, Inc. v. Sociedad Nationale Industria Applicazioni Viscosa, 428 F. Supp. 1237, 1253 (S.D.N.Y. 1977) (greater showing of inconvenience required). See also Farmanfarmaian v. Gulf Oil Corp., 588 F.2d 880, 882 (2d Cir. 1978).

1019 U.S. (6 Wheat.) 264 (1821).

11 It is most true, that this Court will not take jurisdiction if it should not: but it is equally true, that it must take jurisdiction, if it should. The judiciary cannot, as the legislature may, avoid a measure, because it approaches the confines of the constitution. We cannot pass it by, because it is doubtful. With whatever doubts, with whatever difficulties, a case may be attended, we must decide it, if it be brought before us. We have no more right to decline the exercise of jurisdiction which is given, than to usurp that which is not given. The one or the other would be treason to the constitution.

Id. at 404 .

12 E.g., McClellan v. Carland, 217 U.S. 268, 282 (1910); Ex parte Young, 209 U.S. 123, 
Court has flatly renounced $\mathrm{it}_{,}{ }^{13}$ and today a variety of doctrines exists under which the federal courts may decline to exercise their jurisdiction. As early as 1801, federal admiralty courts used their discretion to decline to exercise jurisdiction over some suits between foreigners, ${ }^{14}$ a practice approved by the Supreme Court in 1885. ${ }^{15}$ More recently, the Court developed the equitable abstention doctrines, relegating some cases to state courts because of considerations of federalism, comity, and avoidance of constitutional questions. $^{16}$

\section{A. The Foundation for Forum Non Conveniens: Gulf Oil}

In Gulf Oil Corp. v. Gilbert, ${ }^{17}$ the Supreme Court held that federal courts have discretion, in exceptional circumstances, to dismiss a suit on the basis of forum non conveniens. Gulf Oil was a diversity suit brought in the Southern District of New York for recovery on a tort committed in Virginia. ${ }^{18}$ The plaintiff's warehouse in Lynchburg, Virginia had been destroyed by fire, allegedly as a result of the defendant's negligence in delivering gasoline to the warehouse tanks. The plaintiff was a Virginian, the defendant was doing business in Virginia, the tort occurred in Virginia, and almost all of the witnesses lived in Virginia. The defendant also sought to implead a Virginia party. The plaintiff filed suit in New York, apparently in the hope that a New York jury would be more generous in awarding damages than a Virginia jury. The district court dismissed the suit on grounds of forum non conveniens, in favor of a Virginia forum, ${ }^{18}$ the court of appeals reversed, ${ }^{20}$ and the

142-43 (1908); Hyde v. Stone, 61 U.S. (20 How.) 170, 175 (1857).

1s Canada Malting Co. v. Paterson S.S., Ltd., 285 U.S. 413, $422-23$ (1932).

14 E.g., Willendson v. Forsoket, 29 F. Cas. 1283, 1284 (C.C.D. Pa. 1801) (No. 17,682).

${ }_{15}$ The Belgenland, 114 U.S. 355, 364-65 (1885). See generally Bickel, supra note 3.

16 See Colorado River Water Conservation Dist. v. United States, 424 U.S. 800, 813-16 (1976); Younger v. Harris, 401 U.S. 37, 44-45 (1971); Louisiana Power \& Light Co. v. City of Thibodaux, 360 U.S. 25, 28-29 (1959); Burford v. Sun Oil Co., 319 U.S. 315, 317-18, 332-33 (1943); Railroad Comm'n v. Pullman Co., 312 U.S. 496, 500-01 (1941). See generally HaRT \& WeChSLER, supra note 3, at 985-1009; 1A J. Moore, supra note 3, đ 0.203[1]-[2]; $17 \mathrm{C}$. WRIGHT, A. MILLER \& E. COOPER, supra note 3, §§ 4241-4248.

17330 U.S. 501 (1947).

18 Id. at 502-03, 509-11.

10 Gilbert v. Gulf Oil Corp., 62 F. Supp. 291 (S.D.N.Y. 1945), rev'd, 153 F.2d 883 (2d Cir. 1946), rev'd, 330 U.S. 501 (1947).

${ }^{20}$ Gilbert v. Gulf Oil Corp., 153 F.2d 883 (2d Cir. 1946), rev'd, 330 U.S. 501 (1947). The opinion is noted in 14 U. CHI. L. REv. 97 (1946). 
Supreme Court reversed again, upholding the district court's dismissal. ${ }^{21}$

The Court stated that, because of the discretionary nature of forum non conveniens, any attempt to "catalogue" the circumstances that would justify exercise of the doctrine would be unwise. ${ }^{22}$ Instead, the Court listed two sets of factors that should be balanced in ruling on a forum non conveniens motion. The first set includes factors relevant to the convenience of the litigants-access to evidence, transportation costs and availability of subpoenas in securing witnesses, and similar problems of expense and fairness ${ }^{23}$-as well as questions about the court's ability to enforce its remedies. ${ }^{24}$ The second set includes factors pertaining to the public interests of the forum. ${ }^{25}$ For instance, the court should consider protection of its docket from the imposition of cases arising wholly outside of its territorial jurisdiction. In addition, there is an interest in having local controversies tried in the locality in which they arise so that the matter is settled within the view of the community affected.

The standard for forum non conveniens is thus a balance of the interests of the plaintiff, the defendant, and the forum, ${ }^{28}$ weighted strongly in the plaintiff's favor. In balancing these factors, great deference must be given to the plaintiff's choice of forum. It is not sufficient that the plaintiff did not file in the most convenient forum; dismissal for forum non conveniens should be used only to prevent a plaintiff from vexing, harassing, or oppressing his opponent with unnecessary expense or trouble. ${ }^{27}$

\section{B. Subsequent Judicial and Legislative Developments}

The Gulf Oil Court, by giving the doctrine of forum non conveniens a broad scope, empowered federal courts to refuse to hear a large number of cases in which the balance of "inconvenience"

21330 U.S. at 512.

${ }^{22} I d$. at 508 .

23 Id.

${ }^{24}$ Id. See Williams v. Green Bay \& W.R.R., 326 U.S. 549, 556 \& n.7 (1946).

2s 330 U.S. at 508-09.

${ }^{26}$ Most lower courts consider the interests of the defendant and the court as part of the same calculus in deciding a motion for dismissal on grounds of forum non conveniens. See, e.g., Alcoa S.S. Co. v. M/V Nordic Regent, No. 78-7054, slip op. at 5953 (2d Cir. Feb. 25, 1980) (en banc). In Hoffman v. Goberman, 420 F.2d 423, 426-27 (3d Cir. 1970), however, the court treated the two considerations as separate grounds for dismissal.

27330 U.S. at 508. 
and "public interest" weighs strongly in favor of dismissal. As a result of legislative and judicial developments since the Gulf Oil decision, however, the universe of federal cases to which the doctrine is applicable has been significantly narrowed.

Congressional action has wrought a severe limit on forum non conveniens when the preferred forum is another federal court. Section 1404(a) of the Judicial Code, ${ }^{28}$ enacted in $1948,{ }^{29}$ requires the transfer of a cause of action rather than dismissal in such cases. Dismissal is therefore appropriate only when the preferred forum is a court of a foreign country or, in rare circumstances, a state court. ${ }^{30}$

In addition, the Supreme Court's reformulation of due process limitations on the exercise of personal jurisdiction over nonresident defendants ${ }^{31}$ has restricted the applicability of forum non conveniens. Under earlier notions of personal jurisdiction based on a state's physical power over persons and property within its territory, a court could assert jurisdiction over a defendant on the basis of his transitory presence in the state or his ownership of property unrelated to the case but located within the state. ${ }^{32}$ In such situations, forum non conveniens could serve as a useful safety valve to protect a nonresident defendant from having to litigate in a forum wholly unrelated to the controversy between the parties.

Since the Court's decisions in International Shoe Co. $v$. Washington $^{33}$ and Shaffer $v$. Heitner, ${ }^{34}$ however, the same sorts of

28 "For the convenience of parties and witnesses, in the interest of justice, a district court may transfer any civil action to any other district or division where it might have been brought." 28 U.S.C. § 1404(a) (1976). See generally Norwood v. Kirkpatrick, 349 U.S. 29 (1955).

29 Act of June 25, 1948, Pub. L. No. 773, ch. 646, § 1404(a), 62 Stat. 937 (current version at 28 U.S.C. § 1404(a) (1976)).

${ }^{30}$ See Gross v. Owen, 221 F.2d 94, 96 (D.C. Cir. 1955) (no other federal district available); Simon v. Silfen, 247 F. Supp. 762, 763 (S.D.N.Y. 1965) (parallel state action already pending).

${ }^{31}$ Rule 4(e) of the Federal Rules of Civil Procedure incorporates state statutes or rules concerning out-of-state service of process for any federal action not within a special statutory provision allowing nationwide service (and not subject to the "hundred-mile bulge" provided for in FED. R. Crv. P. 4(f)). Thus, the Supreme Court decisions regarding the due process limits on the abilities of state courts to invoke jurisdiction over nonresident persons or corporations are relevant to the jurisdiction of the federal courts.

${ }^{32}$ E.g., Pennoyer v. Neff, 95 U.S. 714 (1877). See generally 2 J. Moore, supra note 3, ifl 4.25[2], 4.41-1[1]. For an example of how little connection with the forum state was required, see Grace v. MacArthur, 170 F. Supp. 442 (E.D. Ark. 1959), holding a defendant subject to Arkansas jurisdiction because he was served with process while in Arkansas airspace on a flight from Memphis to Dallas.

${ }^{33} 326$ U.S. 310 (1945). 
factors that would support an exercise of forum non conveniens ${ }^{s 8}$ will tend to deprive an American court of jurisdiction over the defendant at the outset. ${ }^{36}$ The central concern under the Court's minimum contacts analysis is "the relationship among the defendant, the forum, and the litigation." ${ }^{37}$ Due process protects a defendant from "the burdens of litigating in a distant or inconvenient forum"38 by requiring that it be "reasonable," with regard for the inconvenience to the defendant, to require him to defend the suit in the forum chosen. ${ }^{38}$

The result of these decisions is to reduce severely the number of cases in which forum non conveniens might be considered. Under the minimum contacts analysis, there appear to be only two possible sets of situations in which a forum might obtain personal jurisdiction over a defendant despite having little or no connection to the controversy. First, if a defendant corporation carries on substantial, continuous business operations in the forum state (or, in the case of an individual, actually resides there), it will ordinarily be subject to process even in a case arising entirely out of events taking place in another jurisdiction. ${ }^{40}$ Although the defendant's domicile in the forum state will tend to reduce the inconvenience of litigating there, ${ }^{41}$ the Gulf Oil factors may nevertheless call for dismissal. ${ }^{42}$ Second, personal jurisdiction properly exists for many

34433 U.S. 186 (1977).

${ }^{35}$ See text and notes at notes 23-25 supra.

${ }^{36}$ See note 2 supra. See also Morley, supra note 3.

${ }^{37}$ Shaffer v. Heitner, 433 U.S. at 204.

${ }^{38}$ World-Wide Volkswagen Corp. v. Woodson, 100 S. Ct. 559, 564 (1980).

${ }^{39}$ Id. (quoting International Shoe Co. v. Washington, 326 U.S. 310, 317 (1945)). The burden on the defendant is a "primary concern," but other factors considered are "the forum state's interest in adjudicating the dispute . . . ; the plaintiff's interest in obtaining convenient and effective relief . . . ; the interstate judicial system's interest in obtaining the most efficient resolution of controversies; and the shared interest of the several States in furthering fundamental substantive social policies." Id.

10 E.g., International Shoe Co. v. Washington, 326 U.S. 310, 318 (1945) (dictum) (citing cases). The Court has consistently characterized its rules requiring minimum contacts as due process limitations on the power of a state to affect nonresident defendants. E.g., World-Wide Volkswagen Corp. v. Woodson, 100 S. Ct. 559, 564 (1980).

1 See, e.g., Williams v. Green Bay \& W.R.R., 326 U.S. 549, 559-60 (1946); Burt v. Isthmus Dev. Co., 218 F.2d 353, 357-58 (5th Cir. 1955); Restatement (Second) of Conflict of Laws § 84, Comment $f$ (1971).

12 For example, Gulf Oil (decided after International Shoe) appears to be such a case: The defendant's consent to be sued [through doing business in the forum and designating a state officer for service of process] extends only to give the court jurisdiction of the person; it assumes that the court, having the parties before it, will apply all the applicable law, including in those cases where it is appropriate, its discretionary judgment as to whether the suit should be entertained. In all cases in which the doctrine of 
in rem causes of action relating to a mobile res recently brought into the forum state. ${ }^{43}$ In admiralty, to take the most common example, ships are frequently libelled in ports far away from the locations at which torts or breaches of contract allegedly occurred.44

Despite these developments, which have reduced the importance of forum non conveniens, the doctrine continues to be invoked by many federal courts when the alternative forum is overseas. ${ }^{45}$ Thus, the question frequently arises what showing of "inconvenience" and "public interest" should be required to deprive an American plaintiff of an American forum..$^{46}$ Until recently, the federal courts have been unanimous in holding that a defendant has a far greater burden if dismissal will result in sending an American plaintiff suing in his own right ${ }^{47}$ abroad to litigate his claim. ${ }^{48}$ But in Alcoa Steamship Co. v. M/V Nordic Regent, ${ }^{48}$ the

forum non conveniens comes into play, it presupposes at least two forums in which the defendant is amenable to process; the doctrine furnishes criteria for choice between them.

330 U.S. at 506-07. Accord, Domingo v. States Marine Lines, 340 F. Supp. 811, 816 (S.D.N.Y. 1972) ("Certainly, this district and the Metropolitan area in which it is situated have no conceivable relation to this litigation except for the fact that the defendant happens to be doing business here.").

${ }^{43}$ In Shaffer v. Heitner, 433 U.S. 186 (1977), the Court held that such jurisdiction violates due process if the res has no connection to the controversy, id. at 208-09, 213, but it remarked that jurisdiction would have been proper if the case had involved conflicting claims to the property itself or rights and duties growing out of the defendant's ownership of the property, id. at 207-08. See also id. at $199 \mathrm{n.17}, 207 \mathrm{n.24,} 208 \mathrm{n.29}$ (characterizing such actions as technically quasi in rem rather than in rem).

14 An example of such a case is Alcoa S.S. Co. v. M/V Nordic Regent, No. 78-7054 (2d Cir. Feb. 25, 1980) (en banc). As to the role of forum non conveniens in admiralty law, see generally id., slip. op. at 5958-60.

15 See cases cited note 8 supra.

18 See cases cited note 9 supra.

47 If an American citizen is suing as the subrogee, e.g., United States Merchants' \& Shippers' Ins. Co. v. A/S Den Norske Afrika Og Australie Line, 65 F.2d 392, 394 (2d Cir. 1933), the assignee, e.g., Del Monte Corp. v. Everett S.S. Corp., 402 F. Supp. 237, 243 (N.D. Cal. 1973), or the representative, e.g., Fitzgerald v. Westland Marine, 369 F.2d 499, 502 (2d Cir. 1966), of an alien, no special deference is shown.

${ }^{18}$ See cases cited note 8 supra. There is limited authority (four cases decided in the same district court, three by the same judge) holding that a citizen has an absolute, constitutional right of access to United States admiralty courts. The Epsom, 227 F. 158 (W.D. Wash. 1915); The Neck, 138 F. 144 (W.D. Wash. 1905) (Hanford, J.); The Falls of Keltie, 114 F. 357 (D. Wash. 1902) (Hanford, J.); Bolden v. Jensen, 70 F. 505 (D. Wash. 1895) (Hanford, J.). See Bickel, supra note 3, at 43-44. The decisions relied on Chief Justice Marshall's argument in Cohens v. Virginia, 19 U.S. (6 Wheat.) 264, 404 (1821), an argument that has subsequently been rejected. See text and notes at 25-30 supra. See also note 79 infra.

49 No. 78-7054 (2d Cir. Feb. 25, 1980) (en banc). The district court dismissed the suit on grounds of forum non conveniens, 453 F. Supp. 10, 12-13 (S.D.N.Y. 1978), and the appellate panel affirmed, $1979 \mathrm{Am}$. Mar. Cas. 13 (2d Cir. 1978). The panel on rehearing vacated 
Second Circuit en banc departed from this view, holding that the plaintiff's citizenship is not a proper factor in considering forum non conveniens. In addition, the court noted that this was a growing trend in the state courts. ${ }^{\text {so }}$

The question of what showing should be required is by its nature difficult to resolve. In theory, the plaintiff's citizenship has no bearing on the relevant interests of the defendant: a suit brought in an allegedly inconvenient forum is neither more nor less expensive or oppressive to the defendant when the suit is brought by an American rather than foreign citizen. On the other hand, the plaintiff's citizenship may be directly or indirectly relevant to the interests of the plaintiff and the forum. It may be more convenient for the plaintiff to litigate in his home forum than elsewhere. ${ }^{\text {s1 }}$ The forum arguably has a general duty to provide its citizens with free

the first panel decision and reversed the district court, 1979 Am. Mar. Cas. 1, 6 (2d Cir. 1979), and the Second Circuit en banc vacated the decision of the panel on rehearing and affirmed the district court, No. 78-7054, slip op. at 5973 (2d Cir. Feb. 25, 1980) (en banc).

so No. 78-7054, slip op. at 5960-63 (2d Cir. Feb. 25, 1980) (en banc). See Turner v. Evers, 31 Cal. App. 3d Supp. 11, 24-25; 107 Cal. Rptr. 390, 399-400 (1973); Winsor v. United Air Lines, Inc., 52 Del. 161, 154 A.2d 561 (1958); Carr v. Bio-Medical Applications of Wash., Inc., 366 A.2d 1089, 1093 (D.C. 1976); Universal Adjustment Corp. v. Midland Bank, Ltd., 281 Mass. 303, 184 N.E. 152 (1933); Gore v. United States Steel Corp., 15 N.J. 301, 104 A.2d 670, cert. denied, 348 U.S. 861 (1954); Silver v. Great Am. Ins. Co., 29 N.Y.2d 356, 278 N.E.2d 619, 328 N.Y.S.2d 398 (1972); In re Dunkley, 89 Wash. 2d 777, 783, 575 P.2d 1071, 1074 (1978). And in three directly analogous recent cases, New York courts have dismissed actions brought by New York plaintiffs in favor of foreign forums. Irrigation \& Indus. Dev. Corp. v. Indag S.A., 37 N.Y.2d 522, 337 N.E.2d 749 (1975) (preferred forum in Switzerland); Mollendo Equip. Co. v. Sekisan Trading Co., 56 A.D.2d 750, 392 N.Y.S.2d 427 (1977) (preferred forum in Japan), aff'd mem., 43 N.Y.2d 916, 374 N.E.2d 623, 403 N.Y.S.2d 729 (1978); Hormel Int'l Corp. v. Arthur Andersen \& Co., 55 A.D.2d 905, 390 N.Y.S.2d 457 (1977) (preferred forum in Spain).

The Supreme Court has twice declined to decide whether forum non conveniens in federal courts is governed by federal law or by the law of the forum state. See Gulf Oil Corp. v. Gilbert, 330 U.S. 501, 509 (1947); Williams v. Green Bay \& W.R.R., 326 U.S. 549, 558-59 (1946). The weight of authority, however, is that forum non conveniens is a question of federal law. For the most complete discussion of the question, see Lapides v. Doner, $248 \mathrm{~F}$. Supp. 883 (E.D. Mich. 1965) (forum non conveniens governed by federal law). For cases holding that the doctrine is governed by federal law, see Founding Church of Scientology v. Heinrich Bauer Verlag, 536 F.2d 429, 434 n.13 (D.C. Cir. 1976); Altman v. Central of Ga. Ry., 363 F.2d 284 (D.C. Cir.), cert. denied, 385 U.S. 920 (1966); Szantay v. Beech Aircraft Corp., 349 F.2d 60 (4th Cir. 1965); Willis v. Weil Pump Co., 222 F.2d 261 (2d Cir. 1955); McLouth Steel Corp. v. Jewell Coal \& Coke Co., 432 F. Supp. 10 (E.D. Tenn. 1976); Fiorenza v. United States Steel Int'l, Ltd., 311 F. Supp. 117 (S.D.N.Y. 1969) (mem.); Shulman v. Compagnie Generale Transatlantique, 152 F. Supp. 833 (S.D.N.Y. 1957); Ultra Sucro Co. v. Illinois Water Treatment Co., 146 F. Supp. 393 (S.D.N.Y. 1956). But see Weiss v. Routh, 149 F.2d 193 (2d Cir. 1945) (L. Hand, J.). See generally 1A J. Moore, supra note 3, II $0.317[2]$, at 3230 .

${ }^{51}$ See text and notes at notes 54-62 infra. 
access to its courts, ${ }^{52}$ and a particular duty to protect them against the uncertain hazards of litigation in foreign courts. ${ }^{53}$ In assessing the proper role of plaintiff's citizenship in forum non conveniens decisions, then, it is necessary to examine the legitimacy and importance of these putative interests, and then to consider whether they justify imposing a stricter standard on a defendant seeking dismissal on grounds of forum non conveniens whose opponent is an American rather than foreign citizen.

\section{The Plaintiff's Convenience}

A court considering a motion for dismissal on grounds of forum non conveniens must accord great weight to the plaintiff's convenience, as represented in his choice of forum. ${ }^{54}$ The plaintiff's citizenship may perhaps be a good proxy for his convenience: all other things being equal, one might well suppose that an American citizen can sue more conveniently at home than abroad.

Citizenship, however, is relevant to convenience primarily insofar as it correlates with residency. A resident American citizen, as a general matter, will be disadvantaged if he is forced to litigate in an unfamiliar legal system in a country to which he must travel a long distance. ${ }^{\text {ss }}$ Such considerations do not apply to an expatriate citizen. For example, in Texaco Trinidad, Inc. $v$. Astro Exito Navegacion S.A., Panama, ${ }^{68}$ a Delaware corporation whose business operations and primary office were in Trinidad brought suit in federal court against two Panamanian corporations. The suit alleged a tortious allision between a Panamanian ship and the plaintiff's jetty in a Trinidadian port. The court dismissed the suit for forum non conveniens, remarking that the plaintiff was a United

${ }^{32}$ See text and notes at notes 78-96 infra.

ss See text and notes at notes 63-77 infra.

s4 See text and note at note 27 supra.

ss In several cases, for example, courts have refused to send American residents overseas because of the burden caused by the sheer distance to the foreign courts. Ciprari v. Servicos Aereos Cruzeiro do Sul, S.A., 232 F. Supp. 433, 443 (S.D.N.Y. 1964); Wahl v. Pan Am. World Airways, 227 F. Supp. 839, 841 (S.D.N.Y. 1964); Shulman v. Compagnie Generale Transatlantique, 152 F. Supp. 833, 836 (S.D.N.Y. 1957). See Restatement (SEcond) of Conflicts of Laws § 84, Comment $\mathrm{f}$ (1971). Cf. Chemical Carriers, Inc. v. L. Smit \& Co.'s Internationale Sleepdienst, 154 F. Supp. 886 (S.D.N.Y. 1957) (treating libelant, a Liberian corporation with its principal place of business in the United States, as an American corporation for forum non conveniens purposes). See also Koster v. Lumbermens Mut. Cas. Co., 330 U.S. 518, 525 (1947).

se 437 F. Supp. 331 (S.D.N.Y. 1977). 
States citizen "solely by virtue of its incorporation," and that it was fully capable of litigating its claim in Trinidad. ${ }^{57}$

In many cases, even residence in the forum will not be a good proxy for convenience: A corporation may "reside" in several forums, ${ }^{58}$ and there is no reason to assume that its American "residence" is necessarily more convenient than its foreign residence. If a company conducts extensive business operations in a foreign jurisdiction, it is probably capable of resolving legal problems stemming from those operations in that jurisdiction without undue burden. Nor is the weakness of residency as a proxy for convenience limited to multinational corporations; an individual plaintiff residing in Buffalo would not necessarily be inconvenienced if he were sent to litigate his claim in Toronto. ${ }^{58}$

The American plaintiff whose suit is dismissed in favor of a foreign forum is also inconvenienced by the foreign language barrier. Even if language does not directly prejudice conduct of a suit, it at least increases litigation costs through the expense of translation. ${ }^{60}$ Again, however, not every dismissal raises the language problem. For one thing, there are numerous English-speaking foreign jurisdictions. Moreover, many of the citizens most likely to become involved in foreign lawsuits (corporations doing business abroad, expatriates, foreign-born citizens, and so on) will be well equipped to conduct their affairs in the language of a foreign forum. ${ }^{61}$

In short, it is undoubtedly true that American citizens, taken as a class, tend to possess characteristics that make foreign litiga-

57 Id. at 334. Much the same could be said of individual American citizens residing abroad. Moreover, it is not essential in all cases that the forum in favor of which jurisdiction is dismissed be the same as the jurisdiction where the citizen resides. An American residing in Paris can presumably litigate at least as conveniently in Brussels as in New York.

$s 8 \mathrm{H}$. Henn, HandbooK of the LaW of Corporations and Other Business Enterprises $\S 85$ (2d ed. 1970). See also 28 U.S.C. $\$ 1391$ (c) (1976) ("A corporation may be sued in any judicial district in which it is incorporated or licensed to do business or is doing business, and such judicial district shall be regarded as the residence of such corporation for venue purposes.").

${ }^{58}$ Conversely, residence in the United States does not necessarily mean convenience of litigation in every federal court; the Buffalo resident may find Toronto far more convenient than, say, a federal district court in San Francisco.

Bo Cf. Founding Church of Scientology v. Heinrich Bauer Verlag, 536 F.2d 429, 436 (D.C. Cir. 1976) (inconvenience to foreign defendant of conducting defense in English is minimal).

${ }^{61}$ This is not meant to suggest that the persons described necessarily form a large majority of all citizens subject to forum non conveniens-only that there are probably a substantial number of potential citizen-plaintiffs for whom language is not a major problem. 
tion inconvenient for them. It is entirely proper that such characteristics be weighed in a court's balancing of the parties' inconveniences. But American citizenship, as such, correlates imperfectly with those characteristics, and therefore should not be used as a facile proxy for the plaintiff's convenience. ${ }^{62}$ Such convenience-related concerns as geography, language barriers, and unfamiliarity with foreign systems should be examined directly on their own merits, case by case, without regard for the passport held by the plaintiff.

\section{Adequacy of Foreign Courts}

Another reason for a court's reluctance to send American plaintiffs overseas may be a general suspicion about the ability of foreign forums to handle fairly and competently suits brought by American plaintiffs. Of course, if a foreign court is simply unavaila$\mathrm{ble}^{63}$ the issue of forum non conveniens does not arise. ${ }^{64}$ But even

${ }^{62}$ An additional reason why citizenship does not fully correlate with convenience is that plaintiffs do not always bring suit in the jurisdictions most convenient to them. See, e.g., Alcoa S.S. Co. v. M/V Nordic Regent, 453 F. Supp. 10, 13 (S.D.N.Y. 1978), aff'd, No. 787054 (2d Cir. Feb. 25, 1980) (en banc). As the Gulf Oil Court noted: "A plaintiff sometimes is under temptation to resort to a strategy of forcing the trial at a most inconvenient place for an adversary, even at some inconvenience to himself." 330 U.S. at 507.

63 At the extreme, the foreign jurisdiction may not have any courts, e.g., Phoenix Canada Oil Co. v. Texaco, Inc., 78 F.R.D. 445 (D. Del. 1978) (military junta in control of Ecuador). The courts of the jurisdiction may be disrupted by civil disturbance, e.g., Flota Maritima Browning de Cuba, S.A. v. The Ciudad de la Habana, 181 F. Supp. 301 (D. Md. 1960), or they may refuse to entertain suits brought by foreign or nonresident plaintiffs, e.g., Hoffman v. Goberman, 420 F.2d 423 ( $3 \mathrm{~d}$ Cir. 1970). If, however, the local statute of limitations has run, or the defendant is not subject to local process, courts typically condition dismissal on the defendant's waiver of the defense and submission to the jurisdiction of the foreign court, e.g., Fitzgerald v. Texaco, Inc., 521 F.2d 448 (2d Cir. 1975), cert. denied, 423' U.S. 1052 (1976); Paper Operations Consultants Int'l Ltd. v. Steamship Hong Kong Amber, 513 F.2d 667 (9th Cir. 1975). Cf. Swift \& Co. v. Compania Colombiana Del Caribe, 339 U.S. 684 (1950) (district court improperly dismissed a libel in rem when it failed to condition the dismissal on the defendant's posting bond in the alternate forum).

Even if a foreign court is technically available to the plaintiff, there may be special considerations that operate practically to deprive him of an opportunity to litigate there. In Oppenheimer v. Louis Rosenthal \& Co., [1937] 1 All E.R. 23 (C.A. 1936), for example, an English court declined to require a Jewish plaintiff of German citizenship to endanger his personal liberty by traveling to Nazi Germany to press his claim against a German defendant. Accord, Wall St. Traders, Inc. v. Sociedad Espanola de Construccion Naval, 245 F. Supp. 344 (S.D.N.Y. 1964). See also Fiorenza v. United States Steel Int'l Ltd., 311 F. Supp. 117 (S.D.N.Y. 1969); Odita v. Elder Dempster Lines, Ltd., 286 F. Supp. 547 (S.D.N.Y. 1968).

ot See Gulf Oil, 330 U.S. at 506-07 ("In all cases in which the doctrine of forum non conveniens comes into play, it presupposes at least two forums in which the defendant is amenable to process; the doctrine furnishes criteria for choice between them."); Note, Requirement of a Second Forum for Application of Forum Non Conveniens, 43 MinN. L. Rev. 
if available, a foreign court might fall short in several respects. First, there may be doubt about the competence of a foreign court to find the facts or apply the law presented in the case. Second, procedures of the foreign system may not comport with American concepts of procedural or substantive fairness. Third, the foreign legal system may be suspected of bias against foreigners in general, or against Americans in particular. Finally, it may apply different rules of law that jeopardize the plaintiff's chances of full recovery. ${ }^{65}$

It seems reasonable to ask whether any of these factors (other than anti-American bias) has any relevance at all to the issue of American citizenship as a forum non conveniens concern. The im-

1199 (1959).

${ }^{85}$ Cases involving forum non conveniens motions, by their nature, typically involve events (such as the commission of a tort or the execution, performance, or breach of a contract) alleged to have taken place in a foreign jurisdiction. Under American conflict-of-laws principles, such matters will commonly be subject to foreign law even if litigated in the United States. See generally A. EhrEnzweIG, supra note 3, \$\$ 171-195, 211-226; H. GooDRich \& E. SCOles, HandBooK of the Conflict of Laws $\$ \S 92-114$ (4th ed. 1964); RestateMENT (SECOND) OF CoNfLict of LAws $\$ \S 145,188$ (1971). But that will not always be true, and if the foreign forum's rules concerning choice of law differ from those of the American forum, the choice of forum may substantially affect the plaintiff's recovery. Moreover, even under generally accepted conflicts principles, there are at least two situations in which the two forums may apply different substantive law-where a maritime tort between parties of different nationalities takes place on the high seas, in which case the law applied is the admiralty law of the forum of litigation, see, e.g., The Gylfe v. The Trujillo, 209 F.2d 386, $387 \&$ n.4 (2d Cir. 1954), and where the foreign forum applies a limitation on recoverable damages, see H. Goodrich \& E. Scoles, supra, $\S 91$, at 163 . Indeed, the latter situation frequently provides the real motive for a forum non conveniens motion, despite all the collateral dispute about location of witnesses and such. See, e.g., Alcoa S.S. Co. v. M/V Nordic Regent, No. 78-7054, slip op. at 5971 (2d Cir. Feb. 25, 1980) (en banc); Texaco Trinidad, Inc. v. Astro Exito Navegacion S.A., Panama, 437 F. Supp. 331, 333 (S.D.N.Y. 1977).

Under current conflict-of-laws principles, it is unclear when, if ever, citizenship as such is a factor in choice of law. The general issue of the role of conflict of laws in forum non conveniens determinations is similarly unsettled. Compare Alcoa S.S. Co. v. M/V Nordic Regent, 1979 Am. Mar. Cas. 13, 20 n.3 (2d Cir. 1978) (Van Graafeiland, J., dissenting) (original panel decision), aff'd on rehearing en banc, No. 78-7054 (2d Cir. Feb. 25, 1980) with Alcoa S.S. Co. v. M/V Nordic Regent, 1979 Am. Mar. Cas. 1, 13 (2d Cir. 1979) (Timbers, J., dissenting) (panel rehearing), vacated on rehearing en banc, No. 78-7054 (2d Cir. Feb. 25, 1980). To the extent that it is a factor, however, it is one which may arise in suits brought by aliens as well as citizens, and into which citizenship enters, if at all, only as part of the choice-of-law calculation. See also The Bremen v. Zapata Off-Shore Co., 407 U.S. 1, 8-9 (1972); Cuba R.R. v. Crosby, 222 U.S. 473, 480 (1912). Moreover, given that many (perhaps most) arguably inconvenient suits brought by citizen-plaintiffs will raise no choice-of-law problems, the possibility of conflict-of-laws difficulties presents no justification for any general rule allowing citizenship to weigh against forum non conveniens dismissal. As with every other factor bearing on fairness or convenience, the possibility of choice-of-law problems can better be considered on a case-by-case basis. 
pact of these factors can affect alien plaintiffs as well as American citizens, and a court considering a forum non conveniens motion must weigh the availability, fairness, and competence of the alternative forum whether or not the plaintiff is a citizen. If, by hypothesis, it is unfair in a given case to send an American plaintiff to a foreign court that will try his claim incompetently or limit his recovery, then surely it is equally unfair to send a foreign plaintiff to that same court in a similar case.

One might respond, however, that the presence of an American plaintiff elevates our concern over possible unfairness. While our courts must be careful to assure that dismissal will not work injustice on a foreign plaintiff, they might still exert greater zeal in guarding American citizens against the hazards of foreign litigation. ${ }^{66}$ Moreover, there is one serious problem that is directly associated with citizenship-the possibility of anti-American bias. Such bias may often be difficult to predict in advance, ${ }^{67}$ especially if the foreign jurisdiction is unstable or unfamiliar to the judge. Hence, it may be necessary to adopt a general rule against sending citizens abroad as a sort of prophylactic device to guard against the shortcomings of foreign courts. ${ }^{68}$.

This line of argument rests on two premises. The doctrinal premise-that American citizens deserve greater protection than aliens in forum non conveniens matters-will be examined later in a broader context. ${ }^{69}$ The factual premise - that foreign courts, as a class, are sufficiently likely to be deficient as to justify an absolute or qualified presumption against them-is flatly contradicted by the established rule to the contrary in the analogous context of recognition of foreign judgments. In Hilton $v$. Guyot, ${ }^{70}$ the Supreme Court held that a civil judgment of a foreign court should be

${ }^{68}$ See Alcoa S.S. Co. v. M/V Nordic Regent, No. 78-7054, slip op. at 5979-80 (2d Cir. Feb. 25, 1980) (en banc) (Van Graafeiland, J., dissenting).

${ }^{67}$ Cf. C. Wright, HandBooK of the Law of Federal Courts $\$ 23$, at 86 \& n.11 (3d ed. 1976) (difficulty of showing likelihood of prejudice or local influence in state courts).

68 The California Supreme Court has adopted an alternative device for protecting a state resident's right to a proper forum. While holding that a resident's suit may rarely be dismissed, see Thomson v. Continental Ins. Co., 66 Cal. 2d 738, 427 P.2d 765, 59 Cal. Rptr. 101 (1967), it has permitted stays of such suits, reasoning that a stay permits the California court to continue to assure that justice is done. Ferreira v. Ferreira, 9 Cal. 3d 824, 838, 84041, 512 P.2d 304, 313, 315, 109 Cal. Rptr. 80, 89, 91 (1973). See Archibald v. Cinerama Hotels, 15 Cal. 3d 853, 859 n.4, 544 P.2d 947, 951 n.4, 126 Cal. Rptr. 811, 815 n.4 (1976) (dictum).

${ }^{69}$ See text and notes at notes 78-96 infra.

30159 U.S. 113 (1895). 
recognized unless it is shown that the court lacked jurisdiction, that the judgment was obtained by fraud, that the court was prejudiced, or that the forum's procedures were not likely to permit fair adjudication. ${ }^{71}$ Nor was the Court bothered by the fact that the foreign court, sitting in a civil-law jurisdiction, observed rules of procedure and evidence unlike American rules; a mere difference, without more, it held, does not constitute a sufficient impeachment of the judgment. ${ }^{22}$

71 [W] are satisfied that, where there has been opportunity for a full and fair trial abroad before a court of competent jurisdiction, conducting the trial upon regular proceedings, after due citation or voluntary appearance of the defendant, and under a system of jurisprudence likely to secure an impartial administration of justice between the citizens of its own country and those of other countries, and there is nothing to show either prejudice in the court, or in the system of laws under which it was sitting, or fraud in procuring the judgment. . . , the merits of the case should not, in an action brought in this country upon the judgment, be tried afresh . . . upon the mere assertion of the party that the judgment was erroneous in law or in fact.

Id. at 202-03. Although the quoted passage does not squarely allocate the burden of proving or disproving the fairness and competence of the foreign court, the structure of the Court's opinion reveals that these matters are in the nature of affirmative defenses. The specific holding to which the quoted passages led was that the defendants could not, on the "general ground" of nonrecognition of foreign judgments, seek to relitigate the merits, id. at 203. The Court then proceeded to address a long series of alleged grounds for impeachment of the foreign judgment, among which was the supposed unreliability of civil-law procedure, $i d$. at 204-05; see text and note at note 72 infra. See also Ritchie v. McMullen, 159 U.S. 235 (1895). See generally Restatement (Second) of Conflict of Laws $\$ 98$ (1971); Peterson, Foreign Country Judgments and the Second Restatement of Conflict of Laws, 72 CoLum. L. REv. 220 (1972); von Mehren \& Patterson, Recognition and Enforcement of Foreign-Country Judgments in the United States, 6 Law \& PoL'y INT'u Bus. 37 (1974); von Mehren \& Trautman, Recognition of Foreign Adjudications: A Survey and a Suggested Approach, 81 HaRv. L. Rev. 1601 (1968).

Despite announcing the rule descibed in text, the Hilton Court refused to give conclusive force to a French judgment because France would not give such force to a judgment of an American court without reexamining the merits. 159 U.S. at 210-28. Cf. Ritchie v. McMullen, 159 U.S. 235 (1895) (recognizing Ontario judgment). Assuming that this reciprocity requirement is still good law, see, e.g., H. Goodrich \& E. Scoles, supra note $65, \S 207$, at 392-93; Restatement (Second) of Conflict of Laws $\$ 98$, Comment e (1971), one could argue that the real reason for recognition of foreign judgments rests in the hope that it will induce reciprocal recognition of American judgments. Hilton's reciprocity holding, however, was clearly distinct from its general recognition rule, which came at the end of the Court's discussion of various alleged grounds of impeachment. It appears to provide an exception to the general rule, based not on anything particular to the individual case but on general principles of international mutuality, 159 U.S. at 228. Indeed, the Court held that even in nonreciprocity cases the foreign judgment provides prima facie evidence of a valid claim, $i d$. at 227 , which surely would be anomalous if foreign proceedings were generally suspect. See also id. at 167-71 (recognizing some classes of judgment not subject to a reciprocity requirement). See generally Comment, Reciprocity Rule and Enforcement of Foreign Judgments, 16 Colum. J. Transnat'L L. 327 (1977).

72 Hilton v. Guyot, 159 U.S. at 204-05. See also The Bremen v. Zapata Off-Shore Co., 407 U.S. 1, 12 (1972) (deprecating "a provincial attitude regarding the fairness of other 
The presumption of foreign-court fairness and competence for purposes of recognizing foreign judgments against American citizens (plaintiff or defendant) is inconsistent with a presumption of deficient foreign courts for purposes of forum non conveniens. A dismissal on grounds of forum non conveniens has no formal effect on the substantive claims of an American plaintiff; it affects the claims, if at all, only to the extent that the difference in forum affects the result of the litigation. In the Hilton situation, by contrast, the recognition of a judgment adverse to the citizen absolutely defeats his claimed right or defense. It would be anomalous in the extreme to presume that foreign courts as a class are competent to defeat the substantive claims of American citizens but are not competent to entertain them.

An across-the-board presumption against the adequacy of foreign courts is also unjustified in view of the diversity of judicial systems in today's world. There are undoubtedly some foreign judicial systems that are not entirely above suspicion. ${ }^{73}$ With respect to them, given the high level of deference that should be accorded the plaintiff's choice of forum, an American court might justifiably resolve substantial doubts against dismissal. But there are many foreign jurisdictions whose courts are entirely adequate. At the extreme, one might note the existence of several common-law jurisdictions whose procedures and approaches to litigation are close to our own. Beyond that, there are numerous jurisdictions in the civil-law or other traditions whose judicial operations raise no serious questions of fairness or competence.

Indeed, many of the cases in which forum non conveniens is likely to be asserted are ones that a foreign court might try more competently than an American court. If the case is governed by the laws of the foreign forum, ${ }^{74}$ the foreign court will frequently be better able to apply those laws than an American court. Further, since availability of witnesses, view of premises, and access to

tribunals").

${ }_{73}$ See Alcoa S.S. Co. v. M/V Nordic Regent, No. 78-7054, slip op. at 5980 n.9 (2d Cir. Feb. 25, 1980) (en banc) (Van Graafeiland, J., dissenting). In fact, however, it is rare for an American court to refuse recognition to a foreign judgment because of deficiencies in the rendering forum. Von Mehren \& Patterson, supra note 71, at 59. But cf. Carl Zeiss Stiftung v. V.E.B. Carl Zeiss, Jena, 293 F. Supp. 892, 906-07 (S.D.N.Y. 1968) (East German courts impeached as not independent), modified, 433 F.2d 686 (2d Cir. 1970), cert. denied, 403 U.S. 905 (1971). Cf. Mobile Tankers Co. v. Mene Grande Oil Co., 363 F.2d 611, 614-15 (3d Cir.) (refusing forum non conveniens dismissal because of inadequate foreign procedures), cert. denied, 385 U.S. 945 (1966).

74 See note 65 supra. 
sources of evidence are major factors in the forum non conveniens balance, ${ }^{75}$ a convenient foreign forum will nearly always have an advantage over an inconvenient American forum in ascertaining the facts.

Even with regard to anti-American bias, the presumption seems to be inaccurate: too many differences exist among American citizens. For example, a multinational corporation doing business overseas might be viewed more as an injured local party than as an outsider;" conversely, in some countries, resentment of "foreign capitalists" may present a greater problem than any hypothetical bias against American expatriates or tourists. And surely the defendant's situation is relevant to an evaluation of possible bias against the plaintiff. If he is a fellow American, or a citizen of a third country, he may be able to show that any danger of bias affects him at least as much as the American plaintiff.

In short, while concerns about the quality of justice in the alternative forum must certainly be examined by a court considering a forum non conveniens motion, such concerns are best dealt with on a case-by-case basis, with regard to both the adequacy of the alternative forum in general and the facts presented in the particular case. That some other foreign judicial forums fall below the standards of American courts does not justify a refusal to dismiss in favor of a competent forum if the defendant is otherwise entitled to dismissal whether or not his opponent is an American citizen. ${ }^{77}$

\section{The Citizen's Right of Access}

The arguments considered up to this point for giving special consideration to citizenship in the forum non conveniens balance have rested on the supposition that dismissal in favor of a foreign forum may work some concrete, articulable prejudice on an American plaintiff. It has been hypothesized that litigation overseas may subject the American litigant to undue inconvenience, biased officials, unfair procedures, or incompetent courts. Quite apart from

${ }^{75}$ See Gulf Oil, 330 U.S. at 508; text and notes at notes 22-23 supra.

${ }^{76}$ See, e.g., Texaco Trinidad, Inc. v. Astro Exito Navegacion S.A., Panama, 437 F. Supp. 331 (S.D.N.Y. 1977).

${ }^{77}$ See also Archibald v. Cinerama Hotels, 15 Cal. 3d 853, 859 n.4, 544 P.2d 947, 951 n.4, 126 Cal. Rptr. 811, 815 n.4 (1976) (dictum) ("a California court should assure a California resident a forum for redress of grievances, but need not provide that forum itself if an available foreign court would be a more convenient place of trial"). 
any threat of actual prejudice, however, it may be argued that an American citizen, by reason of that status alone, has a right of access to courts of the United States-if not an absolute right, ${ }^{78}$ then at least a claim superior to that of an alien-that is subject to defeasance on forum non conveniens grounds only on a stronger showing than is necessary to dismiss a foreign plaintiff's suit. ${ }^{79}$ This argument rests primarily on the notion that the federal courts exist for the benefit and protection of American citizens and their rights. In addition, citizens arguably have a special right to use the courts because they support those courts with their taxes. Upon examination, however, neither line of argument is sufficient to support the conclusion.

\section{A. The "Benefit and Protection" of American Citizens}

Several courts have attempted to justify a special concern for citizen-plaintiffs by arguing that the federal courts were created to protect and benefit citizens of the United States. ${ }^{80}$ While this

${ }^{78}$ See text and notes at notes 10-16 supra.

72 The Second Circuit, in Alcoa S.S. Co. v. M/V Nordic Regent, No. 78-7054 (2d Cir. Feb. 25, 1980) (en banc), suggested that a rule requiring a greater showing against an American plaintiff would collide with a provision in many bilateral treaties to which the United States is a party that grants foreign citizens access to American courts on terms no less favorable than those applicable to American citizens, e.g., Treaty of Friendship, Establishment and Navigation, Feb. 21, 1961, United States-Belgium, 14 U.S.T. 1284, 1289, T.I.A.S. No. 5432; Treaty of Friendship, Commerce and Navigation, Oct. 1, 1961, United StatesDenmark, 12 U.S.T. 908, 912, T.I.A.S. No. 4797. The court reasoned: "The courts either would be obliged to apply this same . . . standard to foreign nationals who are the beneficiaries of such clauses, thus barring dismissal for all practical purposes and crippling the concept of forum non conveniens, or they would have to do violence to our treaty obligations which of course are paramount under the Constitution." Alcoa S.S. Co. v. M/V Nordic Regent, No. 78-7054, slip op. at 5957 (2d Cir. Feb. 25, 1980) (en banc).

The argument is unpersuasive, however. It begs the question of what importance citizenship should play in the forum non conveniens balance. If it is demonstrated that American citizenship, by its own right, should be included in the balance, its inclusion becomes no less proper because treaty beneficiaries also receive the same treatment; the citizenship of foreign-citizen plaintiffs who are not beneficiaries of such treaty provisions would still be irrelevant for purposes of the forum non conveniens balance. Moreover, it is not clear that the treaty provisions were ever intended to have the far-reaching significance the court attributed to them. See id., slip op. at 5984-85, 5895 n.12 (Van Graafeiland, J., dissenting).

${ }^{80}$ Alcoa S.S. Co. v. M/N Nordic Regent, 1979 Am. Mar. Cas. 1, 5-6 (2d Cir. 1979) (panel rehearing), vacated on rehearing en banc, No. 78-7054 (2d Cir. Feb. 25, 1980); Burt v. Isthmus Dev. Co., 218 F.2d 353, 356 (5th Cir.), cert. denied, 349 U.S. 922 (1955); United States Merchants' \& Shippers' Ins. Co. v. A/S Den Norske Afrika Og Australie Line, 65 F.2d 392, 392-93 (2d Cir. 1933) (dictum).

A somewhat similar argument for a right of access might be constructed out of Justice Washington's dictum in Corfield v. Coryell, 6 F. Cas. 546, 551-52 (C.C.E.D. Pa. 1823) (No. 3230 ), that access to state courts is a privilege of state citizenship protected by the privileges 
statement, taken generally, is almost a truism, American courts were not created to benefit Americans in every conceivable situation in which they might choose to bring suit in a federal court. In the words of Justice Holmes, "it should be remembered that parties do not enter into civil relations in foreign jurisdictions in reliance upon our courts. They could not complain if our courts refused to meddle with their affairs and remitted them to the place that established and would enforce their rights."81 Forum non conveniens is not a tool for assigning every case to the most appropriate forum. ${ }^{82}$ It is a protective device, intended to prevent a plaintiff from using his choice of forum to vex, harass, or oppress the defendant. ${ }^{83}$ It is one thing to posit that citizens have a right to use the federal courts to protect or vindicate their legal rights; it is quite another to suppose that they are entitled to use those courts to obtain an unfair advantage over their alien adversaries.84 As Judge Learned Hand observed in a similar context, "[t]hough it is quite true that courts are primarily maintained for the benefit of citizens, access to them is only to secure justice .... " "8s When a federal court makes it more difficult for a defendant to escape an

and immunities clause of article IV, U.S. CoNST. art. IV, § 2, cl. 1. By analogy, access to the federal courts might be considered a privilege of United States citizenship. See also The Slaughter-House Cases, 83 U.S. (16 Wall.) 36 (1873). While such a privilege is not constitutionally protected against infringement by the federal government, $c f$. U.S. ConST. amend. XIV, $\S 1$ (prohibiting state abridgment), it might properly be considered by a federal court exercising its discretion. Such an argument, however, fundamentally misstates the privilege of citizenship intended in article IV. Neither that provision nor Justice Washington's construction of it purports to have anything to do with the duties of a state toward its own citizens; rather, the clause prohibits a state from denying to citizens of sister states what it grants to its own citizens. See Douglas v. New York, N.H. \& H.R.R., 279 U.S. 377 (1929). See generally Simpson, Discrimination Against Nonresidents and the Privileges and Immunities Clause of Article IV, 128 U. PA. L. REv. 379 (1979). If that principle were to apply at all to the federal courts, it would be to forbid them from giving greater consideration to citizens' rights of access than to those of aliens. Cf. Wong Wing v. United States, 163 U.S. 228, 238 (1896) (due process clause, U.S. Const. amend. V, protects aliens as well as citizens).

${ }^{81}$ Cuba R.R. v. Crosby, 222 U.S. 473, 480 (1912).

s2 Some commentators have urged that forum non conveniens be expanded to that end. Ehrenzweig, The Transient Rule of Personal Jurisdiction: The "Power" Myth and Forum Conveniens, 65 YALE L.J. 289 (1956); Morley, supra note 3.

${ }^{83}$ Gulf Oil, 330 U.S. at 508; see text and note at note 27 supra.

st Of course, the impropriety might be considered even greater if the defendant happens to be another American citizen (as might easily happen, if, for example, two American corporations were doing business in a foreign country). The courts do not appear to have noticed this possibility.

${ }^{8 s}$ United States Merchants' \& Shippers' Ins. Co. v. A/S Den Norske Afrika Og Australie Line, 65 F.2d 392, 394 (2d Cir. 1933). 
oppressively inconvenient forum solely because the plaintiff is a citizen, the court is serving an unjust and illegitimate purpose. Indeed, in diversity cases involving aliens, the rule is directly contrary to the purpose of the Constitution's grant of jurisdiction. The legislative history of this provision indicates that it was designed to protect the foreigner from the biases of the state courts rather than to protect the American citizen from the biases of foreign courts. $^{86}$

There is nothing in the Supreme Court's opinion in Gulf Oil to contradict this. ${ }^{87}$ Of course, the problem of the citizen-plaintiff did not arise in that case. ${ }^{88}$ Nevertheless, it seems remarkable that the Court made no mention of any public policy of a citizen's right of access to the courts, ${ }^{88}$ as the Court must have realized that the Gulf Oil decision would become the leading delineation of the forum non conveniens doctrine. Instead, all of the Court's listed "factors of public interest" relate solely to the nexus between the forum and the subject matter of the dispute $e^{90}$-not to the status of the litigants.

\section{B. The Citizen as Supporter of the Courts}

One also might argue that federal courts should give special consideration to American citizens since it is these individuals "whose taxes keep the courts in existence." The most obvious

so At the ratification debate of the Virginia Convention, Madison said: "We well know, sir, that foreigners cannot get justice done them in these [state] courts and this has prevented many wealthy gentlemen from trading or residing among us." 3 Elliot's Debates 583 (1888), quoted in HART \& WECHSLER, supra note 3, at 17.

87 See also text and notes at notes 17-27 supra.

ss Although the plaintiff's citizenship is not reported, he was an individual residing and operating a business in Virginia, the convenient alternate forum. 330 U.S. at 502. Moreover, the Court deliberately avoided deciding whether forum non conveniens is ruled by state or federal law, id. at 509. Thus, the Court left open the question whether, assuming citizenship is relevant at all, it is the plaintiff's Virginia citizenship or his United States citizenship that matters. See generally Lapides v. Doner, 248 F. Supp. 883 (E.D. Mich. 1965); 1A J. MoorE, supra note 3, I 0.317[2], at 3230-33; Note, Erie, Forum Non Conveniens and Choice of Law in Diversity Cases, 53 VA. L. REv. 380 (1967).

80 In Koster v. Lumbermens Mut. Cas. Co., 330 U.S. 518 (1947), the Court mentioned residence (not citizenship) as an important factor, $i d$. at 525 . The context, however, was a discussion of the balance of conveniences, not of any right of access. Similarly, the Gulf Oil Court mentioned the plaintiff's residence in connection with relative conveniences, 330 U.S. at 509, but did not report his citizenship. See also text and notes at notes 55-59 supra; note 88 supra.

90 330 U.S. at 508-09. See text and note at note 25 supra.

- Alcoa S.S. Co. v. M/V Nordic Regent, 1979 Am. Mar. Cas. 1, 6 (2d Cir. 1979) (panel rehearing), vacated on rehearing en banc, No. 78-7054 (2d Cir. Feb. 25, 1980). Accord, Al- 
problem with this argument is that there is no necessary connection between the status of American citizen and that of federal taxpayer. A resident alien may pay considerable American taxes, while a company incorporated in the United States but conducting all of its business elsewhere may pay little or none. One federal court that offered this justification for its reluctance to send citizens abroad cited Douglas v. New York, New Haven \& Hartford Railroad ${ }^{92}$ as supporting authority. ${ }^{93}$ But the Douglas case is readily distinguishable. In Douglas, the Court held that a state could take residence into account in granting access to its courts without violating the privileges and immunities clause ${ }^{94}$ because residents support the courts with their tax money. While a citizen may or may not pay taxes, a resident of the forum is almost certain to pay one state tax or another. The court's reliance on Douglas for the proposition that citizens, as taxpayers, are entitled to special deference seems misplaced.

Another fundamental problem with the argument is the assumption that, even if a citizen does pay taxes, he is entitled to preferential access to the federal courts. Taxpayers support many governmental services, but access to those services is usually unrelated to one's tax-paying status. Rather, the government typically applies its facilities so as best to achieve their purposes, and then defrays the expenses out of general revenues not connected to the taxpayers' use of government programs. Thus, the federal courts are open to any party-citizen, resident, taxpayer, or one who is none of those-so long as the suit is proper as to jurisdiction and venue and not subject to dismissal under forum non conveniens, abstention, or similar discretionary doctrines. ${ }^{95}$ Again, the fact that taxpayers financially support the federal government generally is not by itself sufficient to confer standing to challenge the constitutionality of federal statutes. ${ }^{86}$ While the argument that taxpayers should get something for their expenditures has rhetorical appeal,

coa S.S. Co. v. M/V Nordic Regent, No. 78-7054, slip op. at 5975 (2d Cir. Feb. 25, 1980) (en banc) (Oakes, J., dissenting).

82279 U.S. 377, 387 (1929).

${ }^{83}$ Alcoa S.S. Co. v. M/V Nordic Regent, 1979 Am. Mar. Cas. 1, 4-6 (2d Cir. 1979), vacated on rehearing en banc, No. 78-7054 (2d Cir. Feb. 25, 1980).

o4 U.S. CoNST. art. IV, \& 2.

95 See text and notes at notes 10-27 supra.

${ }^{96}$ E.g., Frothingham v. Mellon, 262 U.S. 447, 486-89 (1923). But see Flast v. Cohen, 392 U.S. 83 (1968) (taxpayers have standing to challenge public expenditures violating establishment clause, U.S. CoNST. amend. I). 
the status of the federal taxpayer generally does not entitle one to special access to federal facilities. The doctrine of forum non conveniens should remain faithful to this principle by not granting special access to the American courts for plaintiffs solely because of their citizenship.

\section{ConcLusion}

Forum non conveniens, despite its name, is not primarily a doctrine of convenience, but an " 'instrument of justice." "פr It serves chiefly to protect defendants from a choice of forum so inconvenient as to impair their ability to defend their legal rights in court. When a federal court considers a plaintiff's American citizenship in the forum non conveniens balance as a factor weighing against dismissal, it is actually requiring one class of defendants to endure a higher level of oppression and harrassment than would otherwise be its lot, on the sole ground that the parties it opposes are American citizens. When that factor is given nearly conclusive force, those defendants are relegated to litigation that is unduly burdensome.

Yet there is no valid basis for according such weight to citizenship. Citizenship itself carries no presumptive right of access to the federal courts sufficient to allow citizens to sue in inconvenient forums. Nor does citizenship serve as an adequate proxy for other factors that legitimately weigh against dismissal on grounds of forum non conveniens. In particular cases in which the plaintiff's American residence touches upon some other factors-the plaintiff's convenience, for example, or possible bias in the alternative forum-such factors can be dealt with adequately on their merits, case by case. The mere fact of citizenship, however, has no place in the calculus of forum non conveniens.

Marc O. Wolinsky

${ }^{87}$ Williams v. Green Bay \& W.R.R., 326 U.S. 549, 554 (1946) (quoting Rogers v. Guaranty Trust Co., 288 U.S. 123, 151 (1933) (Cardozo, J., dissenting)). 